\title{
BMJ Open Factors associated with presenting late or with advanced HIV disease in the Netherlands, 1996-2014: results from a national observational cohort
}

Eline L M Op de Coul, ${ }^{1}$ Ard van Sighem, ${ }^{2}$ Kees Brinkman, ${ }^{3}$ Birgit H van Benthem, ${ }^{1}$ Marchina E van der Ende, ${ }^{4}$ Suzanne Geerlings, ${ }^{5}$ Peter Reiss, ${ }^{2}$ for the ATHENA national observational HIV cohort

To cite: Op de Coul ELM, van Sighem A, Brinkman K, et al. Factors associated with presenting late or with advanced HIV disease in the Netherlands, 1996-2014: results from a national observational cohort. BMJ Open 2016:6:e009688. doi:10.1136/bmjopen-2015009688

- Prepublication history for this paper is available online. To view these files please visit the journal online (http://dx.doi.org/10.1136/ bmjopen-2015-009688).

Received 11 August 2015 Revised 28 September 2015 Accepted 16 October 2015

CrossMark

For numbered affiliations see end of article.

Correspondence to Dr Eline LM Op de Coul; eline.op.de.coul@rivm.nl

\section{ABSTRACT}

Objectives: Early testing for HIV and entry into care are crucial to optimise treatment outcomes of HIV-infected patients and to prevent spread of HIV. We examined risk factors for presentation with late or advanced disease in HIV-infected patients in the Netherlands.

Methods: HIV-infected patients registered in care between January 1996 and June 2014 were selected from the ATHENA national observational HIV cohort. Risk factors for late presentation and advanced disease were analysed by multivariable logistic regression. Furthermore, geographical differences and time trends were examined.

Results: Of 20965 patients, 53\% presented with latestage HIV infection, and 35\% had advanced disease. Late presentation decreased from $62 \%$ (1996) to $42 \%$ (2013), while advanced disease decreased from $46 \%$ to $26 \%$. Late presentation only declined significantly among men having sex with men (MSM; $p<0.001$ ), but not among heterosexual males $(p=0.08)$ and females $(p=0.73)$. Factors associated with late presentation were: heterosexual male (adjusted OR (aOR), $1.59 ; 95 \% \mathrm{Cl} 1.44$ to 1.75 vs MSM), injecting drug use (2.00; $\mathrm{Cl} 1.69$ to 2.38 ), age $\geq 50$ years (1.46; $\mathrm{Cl} 1.33$ to 1.60 vs 30-49 years), region of origin (South-East Asia 2.14; 1.80 to 2.54, sub-Saharan Africa $2.11 ; 1.88$ to 2.36 , Surinam $1.59 ; 1.37$ to 1.84 , Caribbean 1.31; 1.13 to 1.53, Latin America 1.23; 1.04 to 1.46 vs the Netherlands), and location of HIV diagnosis (hospital 3.27; 2.94 to 3.63 , general practitioner $1.66 ; 1.50$ to 1.83 , antenatal screening $1.76 ; 1.38$ to 2.34 vs sexually transmitted infection clinic). No association was found for socioeconomic status or level of urbanisation. Compared with Amsterdam, 2 regions had higher adjusted odds and 2 regions had lower odds of late presentation. Results were highly similar for advanced disease.

Conclusions: Although the overall rate of late presentation is declining in the Netherlands, targeted programmes to reduce late HIV diagnoses remain needed for all risk groups, but should be prioritised for heterosexual males, migrant populations, people aged $\geq 50$ years and certain regions in the Netherlands.

\section{Strengths and limitations of this study}

- Nationwide, longitudinal cohort enabling data analysis over a 17-year period.

- Risk factors for presentation with late or advanced HIV disease.

- Late presentation declined significantly among men having sex with men, but not among heterosexual males and females.

- Co-infections with sexually transmitted infections were either not collected or incomplete and were excluded from the analysis.

\section{INTRODUCTION}

The main public health goal of prevention of HIV infection is to interrupt transmission and to improve treatment outcomes for individual HIV-infected patients. In the Netherlands, primary and secondary HIV prevention includes promotion of condom use, screening programmes for pregnant women and blood donors, routine testing of high-risk populations, early referral into care, and partner notification. ${ }^{1-3}$

To optimise treatment outcomes for individual patients, HIV should be as early as possible but not later than at CD4 cell counts below $350 / \mathrm{mm}^{3}$. ${ }^{4}$ Starting combination antiretroviral therapy (cART) at lower CD4 counts negatively affects prognosis as well as HIV transmission and healthcare costs. ${ }^{5-7}$ The US Department of Health and Human Services (DHHS) HIV treatment guidelines, ${ }^{8}$ which are adopted in the Netherlands, ${ }^{9}$ strongly recommend initiation of cART at CD4 counts of $350-500 / \mathrm{mm}^{3}$ based on clinical evidence, but based on expert opinion cART should also be considered for every patient with CD4 counts $>500 / \mathrm{mm}^{3}$. And as it recently became apparent that starting cART in the early or even acute phase of 
infection improves clinical prognosis, more countries are expected to shift towards early recognition of symptoms of acute infection, early linkage into care and immediate treatment. $^{810}$

In 2012, an estimated 24350 (20 420-31 280) people were living with HIV/AIDS in the Netherlands of whom $34 \%$ were either not diagnosed or diagnosed but not in care. ${ }^{11}$ Of those diagnosed and in care, $54 \%$ was diagnosed late (CD4 counts $\left.<350 / \mathrm{mm}^{3}\right) .{ }^{12}$ A study among HIV patients in Rotterdam identified heterosexual transmission, age of 50 years and older, and being of sub-Saharan African or Asian origin as factors associated with late diagnosis. ${ }^{13}$ The authors showed that more than $75 \%$ of the patients before their late diagnosis already experienced clinical symptoms described as HIV indicator diseases (as published by 'HIV in Europe', an expert group that promotes early diagnosis and earlier care of HIV infections in Europe). ${ }^{14}$

In the present study, we examined the state of late presentation $\left(\mathrm{CD} 4<350 / \mathrm{mm}^{3}\right.$, or AIDS-defining event regardless of CD4 count) and advanced HIV disease $\left(\mathrm{CD} 4<200 / \mathrm{mm}^{3}\right.$, or AIDS-defining event regardless of CD4 count) for all patients registered between 1996 and 2014 in the Netherlands. We also studied whether late presentation or advanced disease were related to specific demographic or socioeconomic variables.

\section{METHODS}

We analysed data from 'Stichting HIV Monitoring' (SHM, HIV Monitoring Foundation) from HIV-infected patients registered between January 1996 and June 2014 in 27 HIV treatment centres in the Netherlands (the ATHENA national observational HIV cohort).$^{12}$ Sociodemographic data (gender, age, region of origin, municipality, degree of urbanisation, socioeconomic status (SES), location of HIV diagnosis, HIV transmission route), and clinical data (CD4 cell counts at diagnosis or first entry into care, year of HIV diagnosis, CDC event at diagnosis) were included in the analyses. CDC events were classified according to the classification of the US Centers for Disease Control and Prevention. ${ }^{15}$ CD4 count at time of diagnosis was defined as the first $\mathrm{CD} 4$ count within 3 months after diagnosis. HIV-infected patients were classified according to a consensus definition as presented by the European Late Presenter Consensus working group, ${ }^{16}$ which defined late presentation if a patient is diagnosed with a CD4+ T-cell count $<350 / \mathrm{mm}^{3}$ or if a patient presents with a CDC-C event (AIDS-defining illness) regardless of CD4 count. Advanced HIV disease was defined as a diagnosis with a CD4+ T-cell count $<200 / \mathrm{mm}^{3}$, or with a CDC-C event regardless of CD4 count. Baseline characteristics of these groups were compared with patients presenting 'timely or non-late' (CD4+ T-cell count $>500 / \mathrm{mm}^{3}$ and no AIDS-defining illness).

Ethnic groups were categorised to reflect the main group of immigrants in the Netherlands, based on country of birth of the patient. The location where patients were tested and diagnosed with HIV was available from 2008 onwards. In case location of diagnosis was missing, location of referral was used. A 'status score' computed by the Netherlands Institute for Social Research (SCP, available at: http://www.scp.nl) was used as a proxy for SES. This score takes into account the average income per household in a given postal code area as well as the percentage of households with low income, without paid job, and with low education level. Scores varied between -3.40 and +5.20 and were divided in five classes: very wealthy (lowest to -1.50 ), wealthy $(-1.50$ to -0.50$)$, average $(-0.50$ to +0.50$)$, less favoured $(+0.50$ to +1.50$)$ and deprived $(+1.50$ to highest). Level of urbanisation was divided in five classes based on the average neighbourhood address density (NAD): highly urbanised (NAD $>2500$ or more addresses $/ \mathrm{km}^{2}$ ), urbanised (NAD 1500-2500 addresses $/ \mathrm{km}^{2}$ ), moderate urban (NAD 1000-1500 addresses $/ \mathrm{km}^{2}$ ), less urbanised (NAD 500-1000 addresses $/ \mathrm{km}^{2}$ ), rural $(\mathrm{NAD}<500$ addresses $\left./ \mathrm{km}^{2}\right)$. Patients were divided into 27 public health regions (areas covered by public health services) based on postal codes of the residence of the patients at the time of diagnosis (available from 2003 onwards), for Geographical Information System (GIS) analysis using the ArcGIS 9.3 software program. Choosing public health regions as level of analysis is more detailed than using provinces $(\mathrm{n}=12)$ and could potentially identify variation due to differences in prevention activities of the public health services.

Trends over time in late presentation and advanced disease for different transmission groups were analysed with the Cochran Armitage trend test for categorical variables. Risk factors for late presentation and advanced disease were analysed by univariable and multivariable logistic regression using the SAS V.9.3 statistical software program. Variables that showed an association of $\mathrm{p}<0.20$ (Wald test, univariable analysis) were included in the multivariable analyses. Multivariable analyses with backward selection included variables with $\mathrm{p}<0.05$ for the likelihood ratio test. As the current treatment guidelines strongly recommend cART for all individuals with CD4+ T-cell count $<500 / \mathrm{mm}^{3}$ based on clinical evidence, ${ }^{89}$ the multivariable analysis was repeated for a larger group of patients, those with 'delayed presentation' (defined as having a CD4 count of $<500 / \mathrm{mm}^{3}$ or AIDS-defining event regardless of $\mathrm{CD} 4$ count) to examine if additional risk factors could be identified. Although the clinical relevance to identify patients with CD4 counts of 350-500/ $\mathrm{mm}^{3}$ is smaller compared with patients with lower CD4 counts, identifying patients with $\mathrm{CD} 4<500 / \mathrm{mm}^{3}$ remains important from the public health perspective to prevent further transmission of HIV. ${ }^{17}$

\section{RESULTS}

Patient characteristics

In total, 22311 HIV-infected patients were registered into care in the Netherlands between 1996 and 2014. 
Patients with HIV-2 ( $\mathrm{n}=97)$, HIV-2/HIV-1 co-infections $(n=61)$, and children under the age of $14(n=550)$ were excluded from the analyses as patterns of CD4 counts at diagnosis might be different. For 20965 (97\%) of the 21603 remaining patients, information regarding AIDS-defining illnesses and CD4 count at diagnosis or at first entry into care at the HIV clinic was available and were included in the analyses. The majority of these patients were men who have sex with men (MSM; 59\%), of Dutch origin (57\%), and living in an area with highest population density (53\%; table 1$)$.

Overall, $73 \%$ were 'delayed' presenters, $53 \%$ presented late and $35 \%$ had advanced HIV disease at diagnosis or entry into care. 'Timely' presenters (27\%) had a median CD4 count of 640 cells $/ \mathrm{mm}^{3}$ (IQR 544$783)$ at diagnosis compared with 150 cells $/ \mathrm{mm}^{3}$ (50270) for late presenters and 80 (30-155) for patients with advanced disease (table 1). Of the 7331 patients who presented with advanced disease, $26 \%$ had AIDS at time of diagnosis. Patients presenting late or with advanced disease were more often diagnosed in a hospital, while patients presenting timely were more often diagnosed at an sexually transmitted infection (STI) clinic.

Percentages of late presentation by main transmission group and region of origin are shown for recent years in figure 1. MSM overall showed the lowest percentages of late presentation, but still varying from $31 \%$ for Surinamese MSM to $54 \%$ for South-East Asian MSM. Highest percentages of late presentation were found among heterosexuals from South-East Asia (women: 79\%, men: 73\%), sub-Saharan Africa (women: 63\%, men: $73 \%$ ) and Surinam (women: 64\%, men: 69\%). A large difference was observed between Dutch heterosexual men and women, with $60 \%$ of men and $36 \%$ of women presenting late.

\section{Trends}

Median CD4 counts at time of HIV diagnosis of the total study population increased significantly from 240 cells/ $\mathrm{mm}^{3}$ in 1996 to 410 cells $/ \mathrm{mm}^{3}$ in 2013 ( $\left.\mathrm{p}<0.001\right)$. The overall percentages of patients entering care late or with advanced disease declined significantly between 1996 and 2013 ( $\mathrm{p}<0.001$ ); from $62 \%$ to $42 \%$ among late presenters and from $46 \%$ to $26 \%$ in patients with advanced disease. Trend analysis of late presentation by main transmission group showed a significant decline for MSM, from $59 \%(\mathrm{n}=274)$ in 1996 to $33 \%(\mathrm{n}=205)$ in $2013(p<0.001)$, but not for heterosexual males $(p=0.08)$ and females $(p=0.73$; figure 2$)$ with 72 respectively 57 cases in 2013. Stratification by age groups at time of diagnosis $(<30,30-49,>50$ years $)$ showed a significant decline of late presentation for each age group among MSM $(p<0.01)$, but for none of the age groups among heterosexuals (data not shown). Trends were very similar for advanced HIV disease and are therefore not shown.
Factors associated with presenting late or with advanced disease

Patients diagnosed in recent years (>2008) had lower odds of late presentation (adjusted OR (aOR) 0.55 ; $95 \%$ CI 0.51 to 0.59 ) compared with patients diagnosed before 2008 (table 2).

Younger patients $(<30$ years of age) had lower odds of late presentation compared with 30-39 year olds (aOR 0.63 , CI 0.59 to 0.68 ), but being older than 50 years of age was associated with increased odds of late presentation (aOR 1.46, CI 1.33 to 1.60 ).

Heterosexual men (aOR 1.59, CI 1.44 to 1.75 ) and injecting drug users (IDUs; OR 2.00, CI 1.69 to 2.38) were more likely to present late compared with MSM, but heterosexual women had similar odds (aOR 0.98, CI 0.89 to 1.08$)$. Yet, it should be noted that although heterosexual males are more likely to present late compared with MSM, in absolute numbers the majority of late presenters in the Netherlands are MSM. Similarly for age groups, although being aged $>50$ years was associated with greater odds of presenting late, the median age of late presenters was 37 (IQR 30-45), so half of the late presenters were aged 37 or under.

In addition, patients originating from South-East Asia (aOR 2.14, CI 1.80 to 2.54), sub-Saharan Africa (aOR 2.11, CI 1.88-2.36), Surinam (aOR 1.59, CI 1.37 to 1.84 ), the Caribbean (aOR 1.31, CI 1.13 to 1.53 ) or Latin America (aOR 1.23, CI 1.04 to 1.46 ) were more likely to present late compared with patients of Dutch origin. Late presentation was also more common in patients who were diagnosed with HIV in a hospital (aOR 3.27, CI 2.94 to 3.63), a general practitioner (GP; aOR 1.66 , CI 1.50 to 1.83 ) or through antenatal screening (aOR 1.76, CI 1.38 to 2.24). SES and population density were not associated with late diagnosis. Stratified models for MSM and heterosexuals showed similar risk factors for late presentation, which was also illustrated by non-significant interaction terms for transmission category with other variables in the overall model including all transmission groups.

The models for advanced disease (table 2) and 'delayed' presentation (not shown) showed the same risk factors with highly similar aORs. However, in the last model, a small association for population density was observed: patients living in an average-urbanised or less-urbanised area had slightly higher odds of presenting 'delayed' (aOR 1.17, CI 1.02 to 1.34 and aOR 1.19, CI 1.03 to 1.38 , respectively) compared with patients living in a highly urbanised area.

\section{Regional differences}

Geostatistics using GIS software was used to provide insight in regional variability in proportions of late diagnoses for the 27 public health regions in the Netherlands in recent years, for the total population (figure 3A) and for MSM separately (figure 3B). Public health regions with overall proportions of late presentation higher than $50 \%$ tended to be more located in the 
Table 1 Characteristics of HIV patients with non-late presentation, late presentation and advanced disease in the Netherlands, January 1996 to June 2014

\begin{tabular}{|c|c|c|c|c|}
\hline & $\begin{array}{l}\text { HIV patients in care, total } \\
(n=20965,100 \%) \\
N(\%)\end{array}$ & $\begin{array}{l}\text { 'Timely' presentation } \\
(\mathrm{n}=5756,27 \%) \\
\mathrm{N}(\%)\end{array}$ & $\begin{array}{l}\text { Late presentation } \\
(n=11182,53 \%) \\
N(\%)\end{array}$ & $\begin{array}{l}\text { Advanced disease } \\
(n=7331,35 \%) \\
N(\%)\end{array}$ \\
\hline \multicolumn{5}{|l|}{ Year of diagnosis } \\
\hline$<2001$ & 7762 (37) & $1631(28)$ & $4803(43)$ & $3373(46)$ \\
\hline $2002-2007$ & 6603 (32) & 1915 (33) & 3441 (31) & $2205(30)$ \\
\hline $2008>$ & $6600(31)$ & $2210(38)$ & $2938(26)$ & $1743(24)$ \\
\hline \multicolumn{5}{|l|}{ Gender } \\
\hline Male & $16877(80)$ & 4717 (82) & $8851(79)$ & $5829(80)$ \\
\hline Female & $4088(20)$ & 1039 (18) & $2331(21)$ & $1502(20)$ \\
\hline \multicolumn{5}{|l|}{ Transmission category } \\
\hline MSM & $12314(59)$ & 3909 (68) & $5717(51)$ & 3535 (48) \\
\hline Heterosexual, male & $2940(14)$ & $525(9)$ & $1984(18)$ & $1425(19)$ \\
\hline $\begin{array}{l}\text { Heterosexual, } \\
\text { female }\end{array}$ & $3636(17)$ & $945(16)$ & $2043(18)$ & $1300(18)$ \\
\hline IDU & 701 (3) & $128(2)$ & $475(4)$ & $336(5)$ \\
\hline Other/unknown & $1374(7)$ & $249(4)$ & $1056(9)$ & $735(10)$ \\
\hline Median age (IQR) & $36(29-44)$ & $35(28-43)$ & $37(30-45)$ & $38(31-46)$ \\
\hline \multicolumn{5}{|l|}{ Municipality } \\
\hline Amsterdam & $6283(30)$ & 1815 (32) & 3198 (29) & 2027 (28) \\
\hline Other & $14682(70)$ & 3941 (68) & $7984(71)$ & $5304(72)$ \\
\hline \multicolumn{5}{|l|}{ Region of origin } \\
\hline The Netherlands & $11913(57)$ & $3643(63)$ & $5866(52)$ & $3808(52)$ \\
\hline Europe, else & $2006(10)$ & $626(11)$ & $962(9)$ & $627(9)$ \\
\hline SSA & 3201 (15) & $544(9)$ & 2156 (19) & 1424 (19) \\
\hline Surinam & $928(4)$ & $215(4)$ & $568(5)$ & $377(5)$ \\
\hline Netherlands & $821(4)$ & $221(4)$ & $443(4)$ & $291(4)$ \\
\hline \multicolumn{5}{|l|}{ Antilles/Caribbean } \\
\hline Latin America & $621(3)$ & $172(3)$ & $306(3)$ & $192(3)$ \\
\hline South-East Asia & $712(3)$ & $132(2)$ & $470(4)$ & $337(5)$ \\
\hline Else/unknown & $763(4)$ & $203(4)$ & 411 (4) & $275(4)$ \\
\hline \multicolumn{5}{|c|}{ Probable country of infection ( $n=15363$ ) } \\
\hline The Netherlands & $11285(54)$ & $3536(61)$ & $5419(48)$ & $3438(47)$ \\
\hline Abroad & 4078 (19) & 997 (17) & $2395(21)$ & $1562(21)$ \\
\hline \multicolumn{5}{|c|}{ Population density $(n=20074)$} \\
\hline Highly urbanised & $11168(53)$ & $3209(56)$ & $5749(51)$ & $3683(50)$ \\
\hline Urbanised & $4298(20)$ & $1215(21)$ & $2294(21)$ & $1502(20)$ \\
\hline Moderate urban & $1901(9)$ & $484(8)$ & $1044(9)$ & $686(9)$ \\
\hline Less urbanised & $1496(7)$ & $391(7)$ & $785(7)$ & $505(7)$ \\
\hline Rural & $1211(6)$ & $343(6)$ & $630(6)$ & $421(6)$ \\
\hline \multicolumn{5}{|l|}{ SES $(n=20028)$} \\
\hline Very wealthy & $1015(5)$ & $297(5)$ & $525(5)$ & $319(4)$ \\
\hline Wealthy & $4396(21)$ & $1278(22)$ & $2214(20)$ & 1391 (19) \\
\hline Average & $5638(27)$ & $1595(28)$ & $2919(26)$ & $1930(26)$ \\
\hline Less favoured & $5125(24)$ & $1454(25)$ & $2675(24)$ & $1771(24)$ \\
\hline Deprived & $3854(18)$ & $1008(18)$ & $2144(19)$ & $1373(19)$ \\
\hline \multicolumn{5}{|c|}{ Location of HIV diagnosis $(n=14938)$} \\
\hline STI clinic & $2782(13)$ & $1217(21)$ & $845(8)$ & $322(4)$ \\
\hline General practitioner & $6468(31)$ & $1967(34)$ & $3081(28)$ & $1777(24)$ \\
\hline Hospital & $5342(25)$ & $1008(17)$ & $3592(32)$ & $2797(38)$ \\
\hline $\begin{array}{l}\text { Antenatal } \\
\text { screening }\end{array}$ & $346(2)$ & $103(2)$ & $175(2)$ & $85(1)$ \\
\hline Else/unknown & $6027(29)$ & $1461(25)$ & $3489(31)$ & 2350 (32) \\
\hline $\begin{array}{l}\text { Median CD4 count } \\
\text { (cells/mms, IQR) }\end{array}$ & $336(140-540)$ & $640(544-783)$ & $150(50-270)$ & $80(30-155)$ \\
\hline \multicolumn{5}{|c|}{$\begin{array}{l}\text { Vertical transmission and children under the age of } 14 \text { excluded; late presentation: } \mathrm{CD} 4<350 \text { cells } / \mathrm{mm}^{3} \text { or AIDS-defining event regardless } \\
\mathrm{CD} 4 \text { count; advanced disease: } \mathrm{CD} 4<200 \text { cells } / \mathrm{mm}^{3} \text { or AIDS-defining event regardless of CD4 count, non-late presentation: CD } 4>500 \text { cells/ } \\
\mathrm{mm} \mathrm{m}^{3} \text { and no AIDS-defining event. } \\
\text { IDU, injecting drug user; MSM, men having sex with men; SES, socioeconomic status; SSA, sub-Saharan Africa; STI, sexually transmitted } \\
\text { infection. }\end{array}$} \\
\hline
\end{tabular}




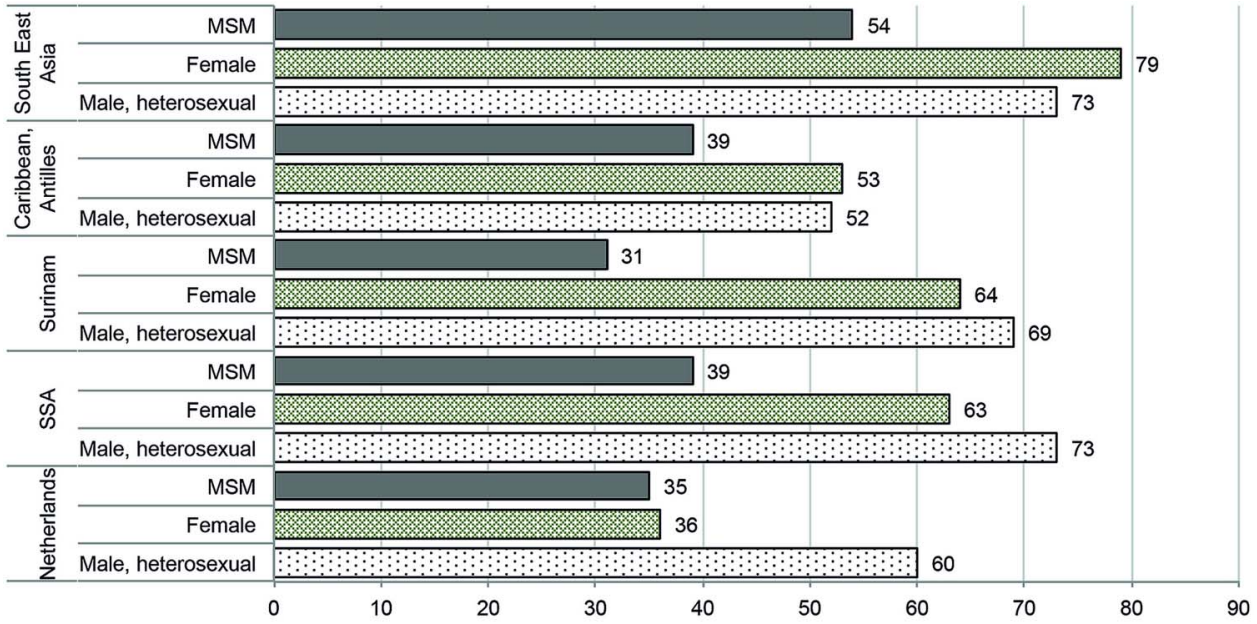

Figure 1 Percentages of late presentation (CD4<350 cells $/ \mathrm{mm}^{3}$ or AIDS-defining event regardless of CD4 count) for $2010-$ 2014 , by transmission group (men having sex with men (MSM), heterosexual male, female) and region of origin.

Eastern part of the country: 'Rivierenland', 'Drenthe', 'Gelderland' and 'Limburg-Noord'. For the first two regions, proportions of late presentation were also high for MSM. Seven regions, mostly in the West (including Amsterdam) or South of the Netherlands, showed proportions of late presentation of $40 \%$ or lower.

With multivariable logistic regression, adjusting for other covariates, we examined whether regional differences could be explained by other factors, such as different distributions of transmission groups or ethnic groups, or whether differences were associated with (unidentified factors in) the region itself (table 2). The model was repeated for a recent period (2010-2014) to improve comparison with the geographic map; however, results were similar to the overall model using the complete database, but CIs were wider and the model fit was weaker (Hosmer and Lemeshow goodness of fit $\mathrm{p}<0.01$ ). In multivariate model, only two regions had significantly higher odds of late presentation compared with Amsterdam (used as reference category due to larger number of patients): 'Rotterdam-Rijnmond' (aOR 1.12,
CI 1.01 to 1.25 , overall model) and 'Groningen' (aOR 1.23 , CI 1.01 to 1.51 , overall model, but also significant in the 2010-2014 model). Of these two regions, 'Groningen' showed the highest proportion of late diagnoses in the geographic map: $48 \%$.

Two Southern regions 'Brabant-Zuidoost' (aOR 0.68, CI 0.78 to 0.82 ) and 'West-Brabant' (aOR 0.78, CI 0.63 to 0.97 ) had significantly lower odds of late presentation compared with Amsterdam (table 2) of which 'Brabant Zuidoost' was significant in both models. The proportion of late diagnoses in that region was $33 \%$ compared with $40 \%$ in Amsterdam.

\section{DISCUSSION}

Of the $20965 \mathrm{HIV}$ patients registered into care between 1996 and 2014 in the Netherlands, 73\% presented 'delayed', 53\% presented late and 35\% had advanced HIV disease. Percentages of presenting late in the course of HIV infection were particularly high among heterosexual males, IDU, patients from sub-Saharan

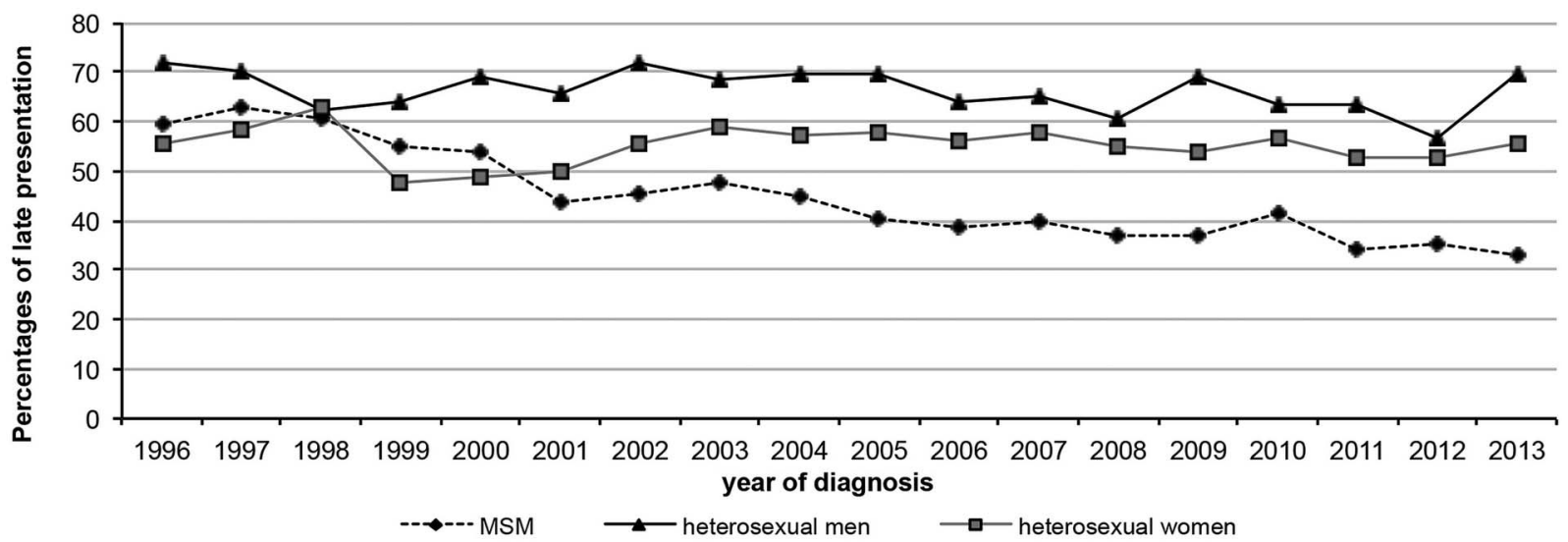

Figure 2 Percentages of late presentation (CD4<350 cells $/ \mathrm{mm}^{3}$ or AIDS-defining event regardless of CD4 count), by year of diagnosis and transmission group (MSM, men having sex with men). 
Table 2 Risk factors for late presentation and advanced disease for HIV patients in the Netherlands, registered between January 1996 and June 2014

\begin{tabular}{|c|c|c|c|c|}
\hline & $\begin{array}{l}\text { Late presentation } \\
\text { Univariable OR } \\
(95 \% \mathrm{Cl})\end{array}$ & $\begin{array}{l}\text { Late presentation } \\
\text { Multivariable aOR } \\
(95 \% \mathrm{CI})\end{array}$ & $\begin{array}{l}\text { Advanced disease } \\
\text { Univariable OR } \\
(95 \% \mathrm{Cl})\end{array}$ & $\begin{array}{l}\text { Advanced disease } \\
\text { Multivariable aOR } \\
(95 \% \mathrm{Cl})\end{array}$ \\
\hline \multicolumn{5}{|l|}{ Period of diagnosis } \\
\hline$<2001$ & 1 & 1 & 1 & 1 \\
\hline 2002-2007 & 0.67 (0.63 to 0.72$)$ & $0.63(0.59$ to 0.68$)$ & 0.65 (0.61 to 0.70$)$ & $0.62(0.58$ to 0.67$)$ \\
\hline $2008>$ & 0.49 (0.46 to 0.53$)$ & $0.55(0.51$ to 0.59$)$ & $0.46(0.43$ to 0.50$)$ & $0.51(0.47$ to 0.55$)$ \\
\hline \multicolumn{5}{|l|}{ Age (years) } \\
\hline$<30$ & 0.70 (0.65 to 0.74$)$ & 0.63 (0.59 to 0.68$)$ & 0.64 (0.60 to 0.68$)$ & $0.59(0.55$ to 0.64$)$ \\
\hline $30-49$ & 1 & 1 & 1 & 1 \\
\hline$>50$ & 1.32 (1.22 to 1.44$)$ & 1.46 (1.33 to 1.60$)$ & 1.36 (1.25 to 1.48$)$ & $1.46(1.33$ to 1.60$)$ \\
\hline \multicolumn{5}{|l|}{ Transmission category } \\
\hline MSM & 1 & 1 & 1 & 1 \\
\hline Heterosexual, male & 2.40 (2.20 to 2.61$)$ & 1.59 (1.44 to 1.75$)$ & 2.34 (2.15 to 2.54$)$ & 1.62 (1.47 to 1.79$)$ \\
\hline Heterosexual, female & 1.48 (1.37 to 1.59$)$ & $0.98(0.89$ to 1.08$)$ & 1.38 (1.28 to 1.49$)$ & $1.03(0.93$ to 1.14$)$ \\
\hline IDU & 2.42 (2.06 to 2.85$)$ & 2.00 (1.69 to 2.38$)$ & 2.29 (1.96 to 2.67$)$ & 1.85 (1.57 to 2.18$)$ \\
\hline Other/unknown & 2.70 (2.39 to 3.05$)$ & $1.73(1.52$ to 1.97$)$ & 2.85 (2.55 to 3.20$)$ & 1.88 (1.66 to 2.13$)$ \\
\hline \multicolumn{5}{|l|}{ Region of origin } \\
\hline The Netherlands & 1 & 1 & 1 & 1 \\
\hline Europe, else & $0.95(0.86$ to 1.04$)$ & $1.13(0.96$ to 1.32$)$ & 0.97 (0.87 to 1.07$)$ & 0.94 (0.83 to 1.05$)$ \\
\hline SSA & 2.13 (1.96 to 2.31$)$ & 2.11 (1.88 to 2.36$)$ & 1.71 (1.58 to 1.85$)$ & 1.64 (1.46 to 1.84$)$ \\
\hline Surinam & $1.63(1.42$ to 1.87$)$ & $1.59(1.37$ to 1.84$)$ & 1.46 (1.27 to 1.67$)$ & $1.37(1.18$ to 1.60$)$ \\
\hline Netherlands Antilles/Caribbean & 1.21 (1.05 to 1.39$)$ & $1.31(1.13$ to 1.53$)$ & 1.17 (1.01 to 1.36$)$ & $1.27(1.08$ to 1.50$)$ \\
\hline Latin America & $1.00(0.85$ to 1.18$)$ & $1.23(1.04$ to 1.46$)$ & 0.95 (0.80 to 1.13$)$ & $1.23(1.02$ to 1.49$)$ \\
\hline South-East Asia & 2.00 (1.71 to 2.35$)$ & $2.14(1.80$ to 2.54$)$ & 1.91 (1.64 to 2.23$)$ & 2.07 (1.75 to 2.45$)$ \\
\hline Else/unknown & $1.20(1.04$ to 1.40$)$ & $1.13(0.96$ to 1.32$)$ & 1.20 (1.03 to 1.40$)$ & 0.99 (0.90 to 1.09$)$ \\
\hline \multicolumn{5}{|l|}{ Residence (PH region) } \\
\hline Amsterdam & 1 & 1 & 1 & 1 \\
\hline Brabant Zuidoost & $0.73(0.62$ to 0.87$)$ & $0.68(0.78$ to 0.82$)$ & 0.77 (0.64 to 0.94$)$ & $0.70(0.57$ to 0.86$)$ \\
\hline West-Brabant & $0.78(0.65$ to 0.95$)$ & 0.78 (0.63 to 0.97$)$ & 0.85 (0.69 to 1.05$)$ & 0.85 (0.67 to 1.06$)$ \\
\hline The Hague & 1.05 (0.93 to 1.18$)$ & 0.89 (0.78 to 1.02$)$ & $1.00(0.88$ to 1.14$)$ & $0.83(0.72$ to 0.96$)$ \\
\hline Groningen & 1.28 (1.07 to 1.54$)$ & $1.23(1.01$ to 1.51$)$ & 1.39 (1.16 to 1.67$)$ & $1.30(1.06$ to 1.60$)$ \\
\hline Rotterdam-Rijnmond & $1.22(1.10$ to 1.34$)$ & $1.12(1.01$ to 1.25$)$ & 1.27 (1.15 to 1.40$)$ & $1.16(1.04$ to 1.29$)$ \\
\hline \multicolumn{5}{|l|}{ Location of referral } \\
\hline STI clinic & 1 & 1 & 1 & 1 \\
\hline General practitioner & 2.09 (1.90 to 2.29$)$ & 1.66 (1.50 to 1.83$)$ & 2.89 (2.54 to 3.29 ) & 2.27 (1.99 to 2.60$)$ \\
\hline Hospital & 4.70 (4.26 to 5.19$)$ & 3.27 (2.94 to 3.63$)$ & 8.40 (7.39 to 9.54$)$ & 5.87 (5.14 to 6.71$)$ \\
\hline Antenatal screening & 2.34 (1.87 to 2.94$)$ & 1.76 (1.38 to 2.24$)$ & 2.49 (1.90 to 3.26$)$ & 2.09 (1.57 to 2.78$)$ \\
\hline Else/unknown & 3.15 (2.86 to 3.47$)$ & 1.93 (1.73 to 2.15$)$ & 4.88 (4.30 to 5.54$)$ & 2.95 (2.57 to 3.38$)$ \\
\hline \multicolumn{5}{|c|}{$\begin{array}{l}\text { Vertical transmission and children under the age of } 14 \text { excluded from the models; late presentation: CD4<350/mm }{ }^{3} \text { or AIDS-defining event } \\
\text { regardless of CD4 count; advanced disease: CD4<200/mm }{ }^{3} \text { or AIDS-defining event regardless of CD4 count. Factors that were not significant } \\
\text { in the multivariable models for late presentation and advanced HIV disease were not shown (probable country of infection, SES, population } \\
\text { density). Municipality was only shown for categories that were significant. Interaction terms were NS. Bold values indicate significant values. } \\
\text { Missing values included in the model. 'Public health region' was significantly associated but not shown in the table due to large number of } \\
\text { categories ( } n=27 \text { ). } \\
\text { aOR, adjusted OR; IDU, injecting drug user; MSM, men having sex with men; NS, non-significant; SES, Socioeconomic status; SSA, } \\
\text { sub-Saharan Africa. }\end{array}$} \\
\hline
\end{tabular}

Africa, South-East Asia or Surinam, patients age 50 and older, and patients diagnosed in hospitals. In addition, certain regions in the Netherlands were associated with a higher risk for late presentation. Risk factors associated with advanced disease were highly similar in this study population, but groups are also overlapping.

One of the strengths of our study is the large number of patients included from a non-selective nationwide, longitudinal cohort, which made it possible to study regional differences as well as time trends over a 17-year period. Also, the quality of the data is high: for $97 \%$ of the eligible patients $\mathrm{CD} 4$ counts at diagnosis or first entry into care and information on AIDS-defining illnesses was available. However, data were less complete for probable country of infection $(73 \%)$ and location of HIV diagnosis $(71 \%)$. Furthermore, variables shown to be associated with late presentation in other settings, ${ }^{18-}$ 23 such as education level or co-infections with STIs, were either not collected or incomplete and could therefore not be included in our analysis. 


\section{A}

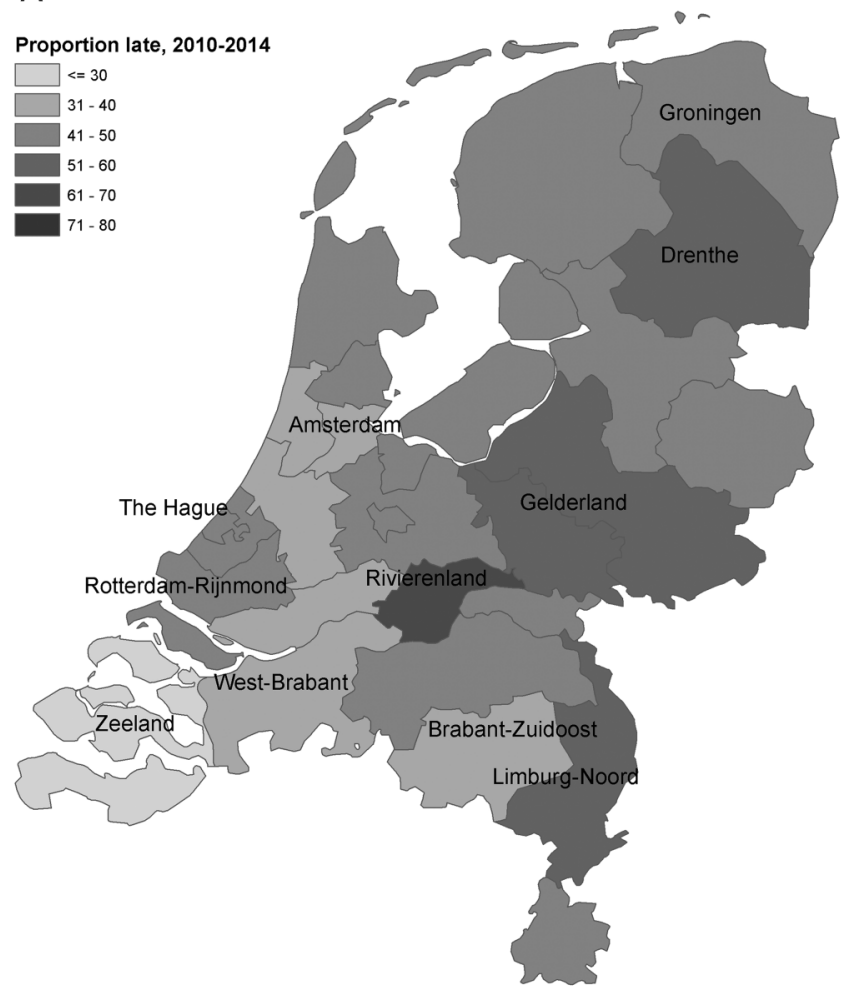

B

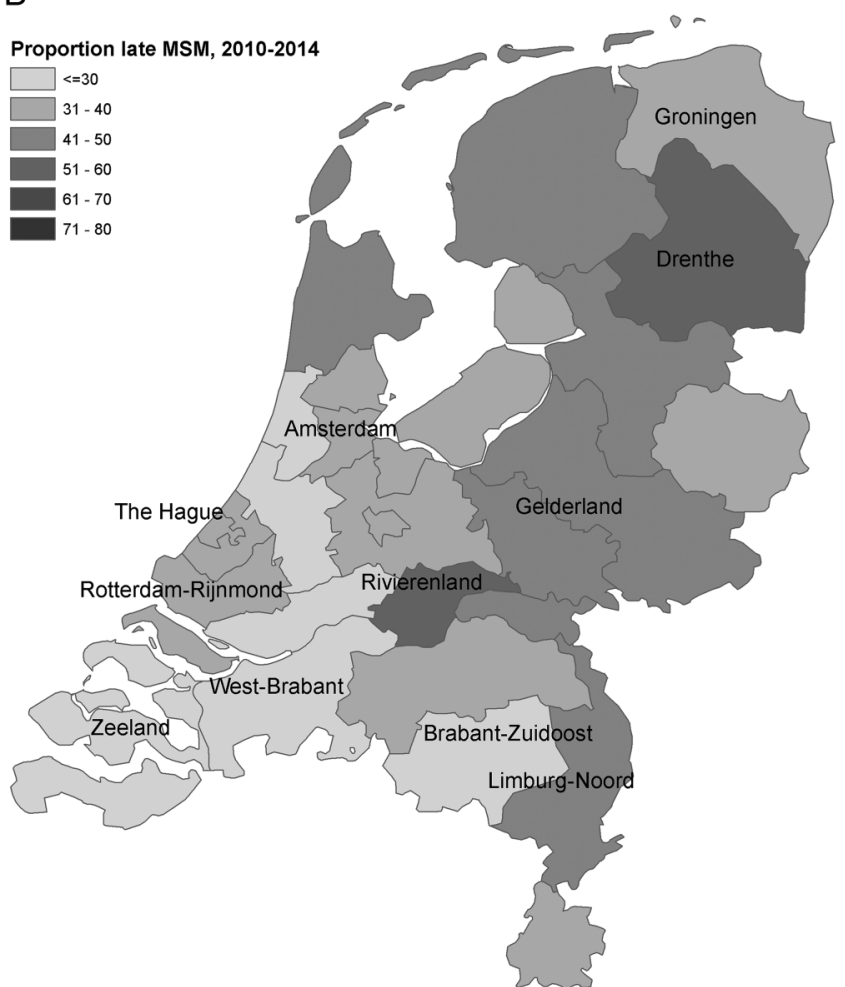

Figure 3 (A) Percentages of late presentation (CD4<350 cells $/ \mathrm{mm}^{3}$ or AIDS-defining event regardless of CD4 count) in 20102014 in the Netherlands, by public health region (overall population). (B) Percentages of late presentation (CD4<350 cells $/ \mathrm{mm}^{3}$ or AIDS-defining event regardless of CD4 count) in 2010-2014 in the Netherlands, by public health region (men having sex with men (MSM) only).

As the importance of early cART initiation for clinical prognosis became more evident ${ }^{10}$ and current treatment guidelines recommend the initiation of cART regardless of $\mathrm{CD} 4$ counts, ${ }^{8} 9$ the overall proportions between $35 \%$ for advanced disease and $73 \%$ for 'delayed' presentation are very high. However, other European studies found comparable high proportions of patients presenting late ${ }^{18-23}$ and risk factors of late presentation were very similar to those found in our study. In most studies, the likelihood of late presentation was lower for MSM compared with other risk groups. Although the overall proportion of late presenters declined over time in the Netherlands, this is mainly due to earlier diagnosis of HIV among MSM, but not among other risk groups. The decline in late presentation among MSM is likely the result of intensified HIV testing strategies, such as opt-out HIV testing at STI clinics and the encouragement of high-risk MSM to test for HIV every 6 months. ${ }^{24}$ In addition, internet facilities for HIV testing and partner notification were established ${ }^{25} 26$ that may have resulted in earlier diagnoses among MSM. ${ }^{3}$ For heterosexuals, especially men and migrant populations, effective HIV testing strategies have been lacking and a more proactive offer of HIV testing in different healthcare settings is urgently needed to reduce the unacceptably high rates of late diagnoses. For example, HIV screening among patients with tuberculosis (TB) should be improved, as for only $51 \%$ of all patients with TB in the Netherlands in 2013 the HIV status was registered, ${ }^{27}$ while the Dutch TB guideline recommends HIV screening for all patients with TB. Furthermore, asylum seekers and refugees are only routinely screened for $\mathrm{TB}$, whereas guidelines in the USA and Canada recommend that all asylum seekers and refugees from HIV-endemic countries should be screened for TB, HIV and hepatitis B. ${ }^{28} 29$ The high HIV prevalence among pregnant asylum seekers from sub-Saharan Africa underlines the importance of offering all newly arriving asylum seekers from high prevalence areas a voluntary HIV test. ${ }^{30}$ Women in the Netherlands may have benefited from antenatal screening, in which HIV is routinely tested, ${ }^{31}$ since the odds of late presentation for women were comparable to MSM.

As one-third of all HIV infections in the Netherlands are diagnosed by GPs, ${ }^{1}$ GPs could play an important role in earlier detection of HIV in specific risk groups. However, GPs tend to have a restrictive policy in offering HIV tests, ${ }^{6}{ }^{32}$ in particular in areas with a low reported HIV prevalence. Recently, the GP guideline for STI/HIV testing ${ }^{33}$ was adjusted to an indicator condition-guided testing strategy ${ }^{14} 34$ including targeted testing of highrisk populations such as people from HIV-endemic areas. Besides ethnic background of patients, we were not able to identify clear associations for socioeconomic 
factors with late presentation such as low education (not collected), and low SES (not significant). ${ }^{18-23} 3536$ Only a small association with 'delayed' presentation was observed for living in less-urbanised areas. In those areas or in areas with low HIV prevalence, the risk for late diagnosis might be higher as GPs may not recognise HIV infections in their practice and people in those areas may be less aware of risks of HIV transmission. This highlights the need to start indicator conditionguided HIV testing in GP practices across the Netherlands. Furthermore, an additional testing strategy could help to reduce the number of undiagnosed HIV patients and patients with more advanced disease, that is, if GPs would offer opt-out HIV testing in all practices located in high prevalence areas ( $>2$ infections $/ 1000$ inhabitants) to their newly registered patients or anyone receiving a blood test. ${ }^{37} 38$

Patients diagnosed in hospitals had the highest odds of presenting late or with advanced disease, which likely illustrates patients who appear with aids-defining events in a hospital and were then tested for HIV. However, HIV indicator condition-guided testing should also be implemented in all hospitals if not already done. Furthermore, direct referral to an HIV treatment centre after diagnosis is needed as a Dutch study showed that $31 \%$ of newly diagnosed patients entered HIV care with a delay of $>4$ weeks, ${ }^{39}$ and $16 \%$ were not registered in care at the end of follow-up ( $>2$ years). Patients who were younger $(<25$ years of age), with non-Western ethnicity or no health insurance were more likely to enter care late after HIV diagnosis as well as those being referred indirectly. The authors concluded that testing those at risk is not sufficient in the Netherlands, but timely entry into care needs to be assured as well. For patients of 50 years and older, early detection and referral has additional importance since these patients tend to have higher mortality rates in the first years of treatment. ${ }^{40}$ In general, older people may perceive themselves at lower risk than younger people, but also healthcare providers may consider HIV testing less often in older patients.

In conclusion, our results can be used to contribute to current efforts to improve HIV testing practices in the Netherlands to prevent late HIV diagnoses and reduce the proportions of undiagnosed. Subsequently, this may result in improved treatment outcomes, ${ }^{10}{ }^{41}$ and less ongoing transmission. In a country where cART is widely available and highly accessible, the high proportions of late presenters are staggering and need to decline. This can only happen if populations at risk are aware of their risks and have themselves tested for HIV, and if indicator condition-guided HIV testing becomes part of routine care in various settings. Targeted programmes to reduce late HIV diagnoses are therefore needed for all risk groups in the Netherlands, but heterosexual males, migrant populations, people older than 50 years of age, and certain regions need special priority.
Author affiliations

${ }^{1}$ Centre for Infectious Disease Control, National Institute for Public Health and the Environment (RIVM), Bilthoven, The Netherlands

${ }^{2}$ Stichting HIV Monitoring, Academic Medical Centre, University of Amsterdam, Amsterdam, The Netherlands

${ }^{3}$ Department of Internal Medicine, OLVG, Amsterdam, The Netherlands ${ }^{4}$ Department of Internal Medicine, Erasmus Medical Centre, Rotterdam, The Netherlands

${ }^{5}$ Department of Internal Medicine, Academic Medical Centre, Amsterdam, The Netherlands

Acknowledgements The authors would like to thank Marianne van der Sande from the RIVM for helpful discussions and reading of the manuscript. They thank Ben Bom and Loes Soetens from the RIVM for their support with the Geographical Information System-analysis. The ATHENA observational cohort is supported by a grant from the Dutch Ministry of Health, Welfare and Sport and was set up, and is maintained, by Stichting HIV Monitoring. It has been made possible through the collaborative efforts of the following physicians working at Netherlands HIV Treatment Centers.

Collaborators Academic Medical Centre of the University of Amsterdam: HIV treating physicians: JM Prins*, TW Kuijpers, HJ Scherpbier, JTM van der Meer, FWMN Wit, MH Godfried, P Reiss, T van der Poll, FJB Nellen, SE Geerlings, M van Vugt, D Pajkrt, JC Bos, WJ Wiersinga, M van der Valk, A Goorhuis, JW Hovius. HIV nurse consultants: J van Eden, A Henderiks, AMH van Hes, M Mutschelknauss, HE Nobel, FJJ Pijnappel, AM Westerman. HIV clinical virologists/chemists: S Jurriaans, NKT Back, HL Zaaijer, B Berkhout, MTE Cornelissen, CJ Schinkel, XV Thomas. Admiraal De Ruyter Ziekenhuis, Goes: HIV treating physicians: M van den Berge, A Stegeman. HIV nurse consultants: S Baas, L Hage de Looff. HIV clinical virologists/chemists: D Versteeg. Catharina Ziekenhuis, Eindhoven: HIV treating physicians: MJH Pronk*, HSM Ammerlaan. HIV nurse consultants: EMHM

Korsten-Vorstermans, ES de Munnik. HIV clinical virologists/chemists: AR Jansz, J Tjhie, MCA Wegdam. Emma Kinderziekenhuis: HIV nurse consultants A van der Plas, AM Weijsenfeld. Erasmus Medisch Centrum, Rotterdam: HIV treating physicians: ME van der Ende*, TEMS de Vries-Sluijs, ECM van Gorp, CAM Schurink, JL Nouwen, A Verbon, BJA Rijnders, HI Bax, RJ Hassing, M van der Feltz. HIV nurse consultants: N Bassant, JEA van Beek, M Vriesde, LM van Zonneveld. Data collection: A de Oude-Lubbers, HJ van den Berg-Cameron, FB Bruinsma-Broekman, J de Groot, M de Zeeuw-de Man, MJ Broekhoven-Kruijne. HIV clinical virologists/chemists: M Schutten, ADME Osterhaus, CAB Boucher. Erasmus Medisch Centrum-Sophia, Rotterdam: HIV treating physicians: GJA Driessen, AMC van Rossum. HIV nurse consultants: LC van der Knaap, E Visser. Flevoziekenhuis, Almere: HIV treating physicians: J Branger*. HIV nurse consultant and data collection: CJHM Duijf-van de Ven. Haga Ziekenhuis, Den Haag: HIV treating physicians: EF Schippers ${ }^{\star}, \mathrm{C}$ van Nieuwkoop, RW Brimicombe. HIV nurse consultants: JM van IJperen. Data collection: $\mathrm{G}$ van der Hut. HIV clinical virologist/chemist. PFH Franck. HIV Focus Centrum (DC Klinieken): HIV treating physicians: A van Eeden*. HIV nurse consultants: W Brokking, M Groot. HIV clinical virologists/chemists: M Damen, IS Kwa. Isala Klinieken, Zwolle: HIV treating physicians: PHP Groeneveld $^{*}$, JW Bouwhuis. HIV nurse consultants: JF van den Berg, AGW van Hulzen. Data collection: GL van der Bliek, PCJ Bor. HIV clinical virologists/chemists: P Bloembergen, MJHM Wolfhagen, GJHM Ruijs. Kennemer Gasthuis, Haarlem: HIV treating physicians: SFL van Lelyveld ${ }^{*}, \mathrm{R}$ Soetekouw. HIV nurse consultants: N Hulshoff, LMM van der Prijt, M Schoemaker. Data collection: N Bermon. HIV clinical virologists/chemists: WA van der Reijden, R Jansen, BL Herpers, DVeenendaal. Leids Universitair Medisch Centrum, Leiden: HIV treating physicians: FP Kroon*, SM Arend, MGJ de Boer, MP Bauer, H Jolink, AM Vollaard. HIV nurse consultants: W Dorama, C Moons. HIV clinical virologists/chemists: ECJ Claas, ACM Kroes. Maasstad Ziekenhuis, Rotterdam: HIV treating physicians: JG den Hollander*, K Pogany. HIV nurse consultants: M Kastelijns, JV Smit, E Smit. Data collection: M Bezemer, T van Niekerk. HIV clinical virologists/chemists: 0 Pontesilli. Maastricht UMC+, Maastricht: HIV treating physicians: SH Lowe*, A Oude Lashof, D Posthouwer. HIV nurse consultants: RP Ackens, J Schippers, $\mathrm{R}$ Vergoossen. Data collection: B Weijenberg Maes. HIV clinical virologists/ chemists: PHM Savelkoul, IH Loo. MC Zuiderzee, Lelystad: HIV treating physicians: S Weijer*, R El Moussaoui. HIV Nurse Consultant. M Heitmuller. 
Data collection: M Heitmuller. Medisch Centrum Alkmaar: HIV treating physicians: W Kortmann*, G van Twillert*, JWT Cohen Stuart, BMW Diederen. HIV nurse consultant and data collection: D Pronk, FA van Truijen-Oud. HIV clinical virologists/chemists: WA van der Reijden, $\mathrm{R}$ Jansen. Medisch Centrum Haaglanden, Den Haag: HIV treating physicians: EMS Leyten*, LBS Gelinck. HIV nurse consultants: A van Hartingsveld, C Meerkerk, GS Wildenbeest. HIV clinical virologists/chemists: JAEM Mutsaers, CL Jansen. Medisch Centrum Leeuwarden, Leeuwarden: HIV treating physicians: MGAvan Vonderen*, DPF van Houte. HIV nurse consultants: K Dijkstra, S Faber. HIV clinical virologists/chemists: J Weel. Medisch Spectrum Twente, Enschede: HIV treating physicians: GJ Kootstra*, CE Delsing. HIV nurse consultants: M van der Burg-van de Plas, H Heins. Data collection: E Lucas. Onze Lieve Vrouwe Gasthuis, Amsterdam: HIV treating physicians: K Brinkman*, PHJ Frissen, WL Blok, WEM Schouten, GEL van den Berk. HIV nurse consultants: AS Bosma, CJ Brouwer, GF Geerders, K Hoeksema, MJ Kleene, IB van der Meché, AJM Toonen, S Wijnands. HIV clinical virologists/chemists: ML van Ogtrop. Radboud UMC, Nijmegen: HIV treating physicians: PP Koopmans, M Keuter, AJAM van der Ven, HJM ter Hofstede, ASM Dofferhoff, R van Crevel. HIV nurse consultants: M Albers, MEW Bosch, KJT Grintjes-Huisman, BJ Zomer. HIV clinical virologists/chemists: FF Stelma. HIV clinical pharmacology consultant. D Burger. Rijnstate, Arnhem: HIV treating physicians: C Richter*, JP van der Berg, EH Gisolf. HIV nurse consultants: G ter Beest, PHM van Bentum, N Langebeek. HIV clinical virologists/chemists: R Tiemessen, CMA Swanink. Sint Lucas Andreas Ziekenhuis, Amsterdam: HIV treating physicians: J Veenstra*, KD Lettinga. HIV nurse consultants: M Spelbrink, H Sulman. Data collection: M Spelbrink, E Witte. HIV clinical virologists/chemists: M Damen, PGH Peerbooms. Slotervaartziekenhuis, Amsterdam: HIV treating physicians: JW Mulder, SME Vrouenraets, FN Lauw. HIV nurse consultants: MC van Broekhuizen, H Paap, DJ Vlasblom. Data collection: E Oudmaijer Sanders. HIV clinical virologists/chemists: PHM Smits, AW Rosingh. Stichting Medisch Centrum Jan van Goyen, Amsterdam: HIV treating physicians: DWM Verhagen. HIV nurse consultants. J Geilings. St Elisabeth Ziekenhuis, Tilburg: HIV treating physicians: MEE van Kasteren*, AE Brouwer. HIV nurse consultants and data collection: BAFM de Kruijf-van de Wiel, M Kuipers, RMWJ Santegoets, B van der Ven. HIV clinical virologists/chemists: JH Marcelis, AGM Buiting, PJ Kabel. Universitair Medisch Centrum Groningen, Groningen: HIV treating physicians: WFW Bierman ${ }^{*}$, HG Sprenger, EH Scholvinck, $S$ van Assen, KR Wilting, Y Stienstra. HIV nurse consultants: $\mathrm{H}$ de Groot-de Jonge, PA van der Meulen, DA de Weerd. HIV clinical virologists/ chemists: HGM Niesters, A Riezebos-Brilman, CC van Leer-Buter. Universitair Medisch Centrum Utrecht, Utrecht: HIV treating physicians: AIM. Hoepelman* MME Schneider, T Mudrikova, PM Ellerbroek, JJ Oosterheert, JE Arends, RE Barth, MWM Wassenberg. HIV nurse consultants: DHM van Elst-Laurijssen, LM Laan, EEB van Oers-Hazelzet, J Patist, S Vervoort, Data collection: HE Nieuwenhuis, R Frauenfelder. HIV clinical virologists/chemists: R Schuurman, F Verduyn-Lunel, AMJ Wensing. VU Medisch Centrum, Amsterdam: HIV treating physicians: EJG Peters*, MA van Agtmael, RM Perenboom, M Bomers, J de Vocht. HIV nurse consultants: LJM Elsenburg. HIV clinical virologists/chemists: AM Pettersson, CMJE Vandenbroucke-Grauls, CW Ang. Wilhelmina Kinderziekenhuis, UMCU, Utrecht: HIV treating physicians: SPM Geelen, TFW Wolfs, LJ Bont. HIV nurse consultants: N Nauta.

Coordinating centre: Stichting HIV Monitoring Director. P Reiss. Data analysis: DO Bezemer, L Gras, Al van Sighem, C Smit. Data management and quality control: S Zaheri, M Hillebregt, V Kimmel, Y Tong. Data monitoring: B Lascaris, R van den Boogaard, P Hoekstra, A de Lang, M Berkhout, S Grivell, A Jansen. Data collection: $L$ de Groot, $M$ van den Akker, D Bergsma, $C$ Lodewijk, R Meijering, B Peeck, M Raethke, C Ree, R Regtop, Y Ruijs, M Schoorl, E Tuijn, L Veenenberg, T Woudstra, Y Bakker, A de Jong, M Broekhoven, E Claessen, MJ Rademaker, L Munjishvili, E Kruijne. Patient registration: B Tuk ( ${ }^{*}$ denotes site coordinating physician).

Contributors ELMOdC, AvS, KB, BHvB, MEvdE, SG and PR were involved in study design. ELMOdC and AvS wrote the paper. ELMOdC and AvS analysed the data. KB, MEvdE, BHvB, SG and PR critically revised the manuscript. All authors approved the final version of the manuscript.

Funding The ATHENA database is supported by the Dutch Ministry of Health, Welfare and Sport and was set up and maintained by Stichting HIV Monitoring.
Competing interests None declared.

Ethics approval This study was based on secondary analysis using data from the ATHENA national observational HIV cohort. The cohort includes anonymised data from all HIV-infected patients living in the Netherlands who receive care in 1 of the 27 HIV treatment centres. Patients are informed of data collection by their treating physician and patients can object to further collection of clinical data according to an opt-out procedure.

Provenance and peer review Not commissioned; externally peer reviewed.

Data sharing statement No additional data are available.

Open Access This is an Open Access article distributed in accordance with the Creative Commons Attribution Non Commercial (CC BY-NC 4.0) license, which permits others to distribute, remix, adapt, build upon this work noncommercially, and license their derivative works on different terms, provided the original work is properly cited and the use is non-commercial. See: http:// creativecommons.org/licenses/by-nc/4.0/

\section{REFERENCES}

1. Van Aar F, Koedijk FDH, van den Broek IVF, et al. Sexually transmitted infections, including HIV, in the Netherlands in 2013. RIVM report 150002005/2014, Bilthoven, 2014. http://www.rivm.nl/ dsresource?objectid=rivmp:254015\&type=org\&disposition=inline

2. National policy plan STI/HIV 2012-2016. "To renew and reinforce". RIVM report 215111001/2011, Bilthoven, 2011. http://www. rijksoverheid.nl/documenten-en-publicaties/rapporten/2011/12/05/ nationaal-soa-hiv-plan-2012-2016-bestendigen-en-versterken.html

3. van Aar F, van Weert Y, Spijker R, et al. Partner notification among men who have sex with men and heterosexuals with STI/HIV: different outcomes and challenges. Int J STD AIDS 2015;26:565-73.

4. Palella FJ Jr, Delaney KM, Moorman AC, et al. Declining morbidity and mortality among patients with advanced human immunodeficiency virus infection. HIV Outpatient Study Investigators. N Engl J Med 1998;338:853-60.

5. Sterne JA, May M, Costagliola D, et al, When To Start Consortium. Timing of initiation of antiretroviral therapy in AIDS-free HIV-1-infected patients: a collaborative analysis of $18 \mathrm{HIV}$ cohort studies. Lancet 2009;373:1352-63.

6. Hermans L, Wensing A, Hoepelman A, et al. Delayed HIV testing in internal medicine clinics-a missed opportunity. Neth $\mathrm{J}$ Med 2012;70:69-73.

7. Krentz HB, Gill J. Despite CD4 cell count rebound the higher initial costs of medical care for HIV-infected patients persist 5 years after presentation with CD4 cell counts less than $350 \mu \mathrm{l}$. AIDS 2010;24:2750-3.

8. Panel on Antiretroviral Guidelines for Adults and Adolescents Guidelines for the use of antiretroviral agents in HIV-1-infected adults and adolescents. Department of Health and Human Services. http://aidsinfo.nih.gov/ContentFiles/AdultandAdolescentGL.pdf

9. Richtlijn HIV. Nederlandse Vereniging van HIV-behandelaren. http:// www.nvhb.nl/richtlijnhiv/index.php/Richtlijn_HIV

10. Lundgren JD, Babiker AG, Gordin F, et al, The INSIGHT START Study Group. Initiation of antiretroviral therapy in early asymptomatic HIV infection. N Engl J Med 2015;373:795-807.

11. Op de Coul ELM, Schreuder I, Conti S, et al. Changing patterns of undiagnosed HIV infection in the Netherlands: who benefits most from intensified HIV test and treat policies? PLOS ONE 2015;10: e0133232

12. Van Sighem A, Gras L, Smit C, et al. Monitoring report 2014. Human immunodeficiency virus (HIV) infection in the Netherlands. Stichting HIV Monitoring 2014, Amsterdam. http://www.HIV-monitoring.nl

13. Schouten M, van Velde AJ, Snijdewind IJM, et al. Late diagnose van hiv-patiënten in Rotterdam. Risicofactoren en gemiste kansen. Ned Tijdschr Geneeskd 2013;157:A5731.

14. HIV in Europe. Guidance document: HIV indicator conditions: Guidance for implementing HIV testing results in adults in health care settings. http://hiveurope.eu/Portals/0/Guidance.pdf.pdf

15. [No authors listed]. 1993 Revised classification system for HIV infection and expanded surveillance case definition for AIDS among adolescents and adults. MMWR Recomm Rep 1992;41 (RR-17):1-19. http://www.cdc.gov/MMWR/preview/MMWRhtm/ 00018871.htm

16. Antinori $A$, Coenen $\mathrm{T}$, Costagiola $\mathrm{D}$, et al. Late presentation of HIV infection: a consensus definition. HIV Med 2010;12:61-4.

17. Girardi E, Sabin CA, Monforte AD. Late diagnosis of HIV infection: epidemiological features, consequences and strategies to encourage earlier testing. J Acquir Immune Defic Syndr 2007;46(Suppl 1):S3-8. 
18. Helleberg M, Engsig FN, Kronborg G, et al. Late presenters, repeated testing, and missed opportunities in a Danish nationwide HIV cohort. Scand J Infect Dis 2012;44:282-8.

19. Girardi E, Aloisi MS, Arici C, et al. Delayed presentation and late testing for HIV: demographic and behavioral risk factors in a multicenter study in Italy. J Acquir Immune Defic Syndr 2004;36:951-9.

20. Couturier E, Schwoebel V, Michon C, et al. Determinants of delayed diagnosis of HIV infection in France, 1993-1995. AIDS 1998;12:795-800.

21. de Olalla PG, Manzardo C, Sambeat MA, et al. Epidemiological characteristics and predictors of late presentation of HIV infection in Barcelona (Spain) during the period 2001-2009. AIDS Res Ther 2011;8:22.

22. Rice B, Elford J, Yin Z, et al. Trends in HIV diagnoses, HIV care, and uptake of antiretroviral therapy among heterosexual adults in England, Wales, and Northern Ireland. Sex Transm Dis 2014;41:257-65.

23. Mocroft A, Lundgren JD, Sabin ML, et al. Risk factors and outcomes for late presentation for HIV-positive persons in Europe: results from the Collaboration of Observational HIV Epidemiological Research Europe Study Group (COHERE). PLoS Med 2013;10:e1001510.

24. Dukers-Muijrers NH, Niekamp AM, Vergoossen MM, et al. Effectiveness of an opting-out strategy for HIV testing: evaluation of 4 years of standard HIV testing in a STI clinic. Sex Transm Infect 2009;85:226-30.

25. Götz HM, van Rooijen MS, Vriens P, et al. Initial evaluation of use of an online partner notification tool for STI, called 'suggest a test': a cross sectional pilot study. Sex Transm Infect 2014;2:195-200.

26. Zuilhof W, Vriens P, Koekenbier R. Versterking van hiv- en soa-bestrijding voor mannen die seks hebben met mannen. Seksoa 2007;389 [in Dutch].

27. Tuberculose Kernpunten 2013. Netherlands Tuberculosis Register ('Nederlands Tuberculose Register'). RIVM-Clb, Bilthoven, 2014. http://www.rivm.nl/dsresource? objectid=rivmp:256106\&type=org\&disposition=inline

28. Centers for Disease Control and Prevention. Public health action plan to integrate mental health promotion and mental illness prevention with chronic disease prevention, 2011-2015. Atlanta: US. Department of Health and Human Services, 2011.

29. Pottie K, Greenaway C, Feightner J, et al. Evidence-based clinical guidelines for immigrants and refugees. CMAJ 2011;183:E824-925.

30. Goosen S, Hoebe JPA, Waldhober Q, et al. HIV prevalence among pregnant asylum seekers in the Netherlands; a nationwide study based on antenatal HIV tests. Section 2.5 from PhD thesis: E.S.M. Goosen. A safe and healthy future? Epidemiological studies on the health of asylum seekers and refugees in the Netherlands. Faculty AMC-UvA, 2014. http://dare.uva.nl/document/2/141325

31. Op de Coul ELM, Hahné $S$, van Weert YW, et al. Antenatal screening for HIV, hepatitis $B$ and syphilis in the Netherlands is effective. BMC Infect Dis 2011;11:185

32. Brinkman K. HIV testing as a normal diagnostic procedure. Neth $\mathrm{J}$ Med 2012;70:56.

33. Heijnen A, Hermanussen R. HIV-verdieping naast de NHG-standaard 'Het soa-consult' [in Dutch]. Amsterdam, 2013. https://www.nhg.org/sites/default/files/content/nhg_org/uploads/ standaard/download/20130903_hiv-verdieping_naast_ denhg-standaard_het_soa-consult_def.pdf

34. Gazzard B, Clumeck N, d'Arminio Monforte A, et al. Indicator disease-guided testing for HIV-the next step for Europe. HIV Med 2008;9(Suppl 2):34-40.

35. Trepka MJ, Fennie KP, Sheehan DM, et al. Late HIV diagnosis: differences by rural/urban residence, Florida, 2007-2011. AIDS Patient Care STDs 2014;28:188-97.

36. Lodi S, Dray-Spira R, Touloumi G, et al, Socio-economic inequalities and HIV writing group for collaboration of observational HIV epidemiological research in Europe (COHERE) in Eurocoord. Delayed HIV diagnosis and initiation of antiretroviral therapy: inequalities by educational level, COHERE in Eurocoord. AIDS 2014:28:2297-306.

37. National Institute for Health Care and Excellence (NICE). Increasing the uptake of HIV testing among men who have sex with men. Public Health Guidance 2011;PH34:6-15. https://www.nice.org.uk/ guidance/ph34/resources/hiv-testing-increasing-uptake-in-men-whohave-sex-with-men-1996297473733

38. National Institute for Health Care and Excellence (NICE). Increasing the uptake of HIV testing among black Africans in England. Public Health Guidance 2011;PH33:6-13. https://www.nice.org.uk/ guidance/ph33/resources/hiv-testing-increasing-uptake-in-blackafricans-1996295794117.

39. van Veen MG, Trienekens S, Heijman T, et al. Delayed linkage to care in one-third of HIV-positive individuals in the Netherlands. Sex Transm Infect 2015;91:603-9.

40. Grabar S, Weiss L, Costagliola D. HIV infection in older patients in the HAART era. $J$ Antimicrob Chemother 2006;57:4-7.

41. Smit C, Hallett TB, Lange J, et al. Late entry to HIV care limits the impact of anti-retroviral therapy in the Netherlands. PLOS ONE 2008;3:e1949. 